\title{
Plant Community and Target Species Affect Responses to Restoration Strategies
}

\author{
John R. Hendrickson ${ }^{1}$ and Corie Lund ${ }^{2}$ \\ Authors are ${ }^{1}$ Rangeland Scientist, Northern Great Plains Research Laboratory, US Department of Agriculture-Agricultural Research Service, Box 459, \\ Mandan, ND 58554, USA; and ${ }^{2}$ Rangeland Management Specialist, US Department of Agriculture-Natural Resources Conservation Service, $6022 n d$ Ave \\ N, Box 872, Hettinger, ND 58639, USA.
}

\begin{abstract}
Increases in Kentucky bluegrass and smooth bromegrass on northern Great Plains rangelands have the potential to negatively impact ecosystem function, lower plant diversity, and alter seasonal forage distribution, but control strategies are lacking in the region. A project was initiated on a heavily invaded 16-ha grassland that had not been grazed or hayed for at least 20 yr. Five restoration treatments and a control were initiated in 2003 on communities dominated by 1) smooth bromegrass (Bromus inermis Leyss.), 2) Kentucky bluegrass (Poa pratensis L.), 3) warm-season native grasses, 4) a mix of introduced species, and 5) smooth bromegrass and Kentucky bluegrass. Restoration treatments were 1) late-April burn, 2) late-April burn followed by imazapic at $511.62 \mathrm{~mL}$ ai $\left.\cdot \mathrm{ha}^{-1}, 3\right)$ imazapic only at the same rate, 4) mowing, 5) mowing followed by litter removal, and 6) control. We found that treatment responses were affected by target species, community category, and year. Generally, burning followed by the herbicide imazapic reduced Kentucky bluegrass in the species composition, but smooth brome was reduced by mowing followed by raking. Burning followed by imazapic reduced live grass biomass in all community categories except the native the year following treatment, but by the third year of the study live grass biomass was maintained across all treatments. In the third year of the study, responses of Kentucky bluegrass, other invasive species, and native grasses to restoration treatment differed depending on community. The use of burning plus imazapic was promising for control of Kentucky bluegrass but its use by producers may be limited by yield reductions in early years. Our data suggest management strategies should vary depending on whether the goal is to reduce one or several invaders, specific invader identity, and community type in which the invader is growing. We also found that the most effective strategy was an adaptive management approach, one where treatments are chosen in response to changes in community composition and depending on resource conditions.
\end{abstract}

\section{Resumen}

El aumento de Poa pratensis y Bromus inermis Leyss en los pastizales de la región norte de las planicies centrales de los EE.UU. podría tener un impacto negativo sobre las funciones del ecosistema, reducir la diversidad vegetal, y alterar la distribución estacional de forraje, sin embargo no existen estrategias de control en la región. Se inició un proyecto en una pradera intensamente invadida de 16 ha que no había sido pastoreada ni henificada por 20 años. Cinco tratamientos de restauración se iniciaron en 2003 en comunidades dominadas por 1) B. inermis, 2) P. pratensis, 3) pastos megatérmicos nativos, 4) una mezcla de especies introducidas, y 5) B. inermis y P. pratensis. Los tratamientos de restauración fueron 1) quema hacia finales de abril, 2) quema hacia finales de abril

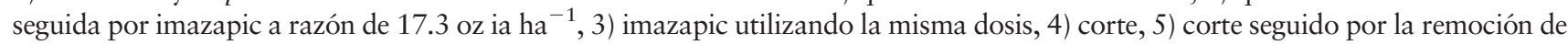
broza, y 6) control. La repuesta a los tratamientos fue afectada por la especie objetivo, la categoría de comunidad vegetal y el año. En general, las quemas seguidas por la aplicación del herbicida imazapic redujeron $P$. pratensis en la composición de especies, sin embargo B. inermis se redujo con corte seguido de rastrillado. La aplicación de quema seguida por imazapic redujo la biomasa viva de pastos en el año siguiente a la aplicación del tratamiento en todas las categorías de comunidad vegetal excepto en la comunidad nativa, sin embargo para el tercer año del ensayo la biomasa viva se mantuvo en todos los tratamientos. En el tercer año del ensayo, la respuesta de $P$. pratensis, otras especies invasoras, y pastos nativos al tratamiento de restauración dependió de la comunidad vegetal. La aplicación de quema seguida de imazapir fue promisoria, pero su uso por parte de productores podría estar limitado por la reducción de rinde en los años iniciales. Nuestros datos sugieren que las estrategias de manejo deberían variar dependiendo de si la meta es reducir una o varias especies invasoras, de la identidad de la especie invasora, y del tipo de comunidad en el que crece la especie invasora. También encontramos que la estrategia más efectiva incluye un enfoque de manejo adaptativo en el que los tratamientos se eligen en función de cambios en la composición de la comunidad y las condiciones del recurso.

Key Words: Bromus inermus, ecological restoration, grassland management, grassland restoration, invasive grasses, Poa pratensis, restoration burns

Research was funded by the Northern Great Plains Research Laboratory, US Department of Agriculture-Agricultural Research Service (USDA-ARS), and by the Dakota Prairie Grasslands, US Forest Service.

USDA-ARS, Northern Plains Area, is an equal opportunity/affirmative action employer and all agency services are available without discrimination.

At the time of the research, Corie Lund was a bioscience aide, Northern Great Plains Research Laboratory, Mandan, ND 58554, USA.

Correspondence: John R. Hendrickson, Northern Great Plains Research Laboratory, USDA-ARS, Box 459, Mandan, ND 58554, USA. Email: john.hendrickson@ars.usda.gov

Manuscript received 10 December 2008; manuscript accepted 7 April 2010.

\section{INTRODUCTION}

Kentucky bluegrass (Poa pratensis L.) and smooth bromegrass (Bromus inermus Leyss.), two introduced, perennial $\mathrm{C}_{3}$ grasses, have been increasing in abundance on northern Great Plains rangelands (Murphy and Grant 2005; Travnicek et al. 2005). Both grasses increase with a lack of herbivory or fire (Grant et al. 2009) and can co-exist in the same rangeland (Murphy and Grant 2005). Kentucky bluegrass and smooth brome have been 
found to disrupt ecosystem function by altering nitrogen cycling and carbon storage (Wedin and Tilman 1996), lowering plant diversity (Pritekel et al 2006; Vaness and Wilson 2007), and shifting seasonal forage production. These detrimental impacts affect livestock production, wildlife habitat, and ecosystem services.

Rangeland managers have used a variety of techniques to control invasive species including burning (Willson and Stubbendieck 1997; DiTomaso et al. 2006), herbicides (Masters et al. 1992; Masters et al. 1996), or a combination of strategies (Travnicek et al. 2005; DiTomaso et al. 2006). Kentucky bluegrass and smooth brome have been negatively impacted by fire (Engle and Bultsma 1984; Schacht and Stubbendieck 1985; Willson and Stubbendieck 1997), but burning can also negatively affect associated cool-season grasses (Engle and Bultsma 1984). Herbicides also have been used to control invasive grasses and forbs (Masters et al. 1992; Masters et al. 1996; Travnicek et al. 2005), but are costly and have raised environmental concerns. Integrated approaches that combine both fire and herbicides have been used in grassland restoration (Masters et al. 1992; Mitchell et al. 1996; Travnicek et al. 2005; DiTomaso et al. 2006) and provide benefits especially when repeated burning is not possible (DiTomaso et al. 2006).

Generally, restoration strategies are targeted on individual invasive species at the population level (i.e., collection of individuals of the same species), but the responses of the associated species, which primarily occur at the community level, are not adequately considered (DiTomaso et al. 2006). When the invasive species and displaced native species differ functionally, targeting restoration strategies at the population level may have positive impacts at the community level. However, when both invasive and native species have similar photosynthetic pathways, restoration strategies can be difficult to implement or create undesirable results (Reed et al. 2005). Similarities in growth and development, as well as competitive strategies, can limit the opportunity to implement restoration strategies and reduce their effectiveness. As an example, fire is often an effective tool for controlling invasive $\mathrm{C}_{3}$ perennials on $\mathrm{C}_{4}$-dominated tallgrass prairies because of differences in growth and development between the two functional groups (Willson 1990). However, Reed et al. (2005) suggested that frequent fire may enhance the dominance of an exotic $\mathrm{C}_{4}$ grass in tallgrass prairie systems because of the ability of the exotic to outcompete native species.

In the northern Great Plains, most litter decomposition is relatively slow and mostly occurs during winter (Hendrickson et al. 2001). While bromegrass may decompose faster than native grasses (Hendrickson et al. 2001), litter from ungrazed patches of Kentucky bluegrass often forms thick mats or "slicks" on the soil surface. The impact of these "slicks" on persistence of Kentucky bluegrass or native grasses is unknown. However, litter and litter dynamics can impact vegetation structure (Facelli and Pickett 1991; Xiong and Nilsson 1999) by reducing productivity (Knapp and Seastedt 1986), species richness (Xiong and Nilsson 1999), and the strength of competitive interactions (Suding and Goldberg 1999).

The invasion of mixed-grass rangelands by Kentucky bluegrass and smooth brome has serious implications for the structure and function of rangelands. In the central Great
Plains, the effects of fire and herbicides have been investigated (Masters et al. 1992; Mitchell et al. 1996). However, unlike the central Great Plains, rangeland in the northern Great Plains is dominated by $\mathrm{C}_{3}$ grasses, which are functionally similar to the invasive Kentucky bluegrass and smooth brome. In this study we evaluated the effect of burning and herbicides alone and in combination along with mowing and litter removal on five different communities in the northern Great Plains. We did this to assess the efficacy of different treatment combinations to reduce the abundance of Kentucky bluegrass and smooth bromegrass in the species composition of different plant communities.

\section{MATERIALS AND METHODS}

The 17-ha study site was located $9 \mathrm{~km}$ south of Mandan, North Dakota, USA (lat $46^{\circ} 45^{\prime} \mathrm{N}$, long $100^{\circ} 55^{\prime} \mathrm{W}$ ). The predominant soils at the site were Belfield-Grail silty clay loams (fine, smectitic, frigid Glossic Natrustolls and fine, smectitic, frigid Pachic Vertic Argiustolls). The site had not been hayed or grazed for approximately $20 \mathrm{yr}$ prior to the initiation of treatments.

In the summer of 2002, we identified 10 different sites within the study location. Each site belonged to one of five plant community categories, each of which was dominated by a different species or species group. Community categories were identified based on visible estimates of the dominant species and two sites for each different community category were included in the study. Plant communities were dominated by 1) Kentucky bluegrass (Poa pratensis L.; Kentucky Bluegrass Dominated), 2) smooth bromegrass (Bromus inermus, Leyss.; Smooth Bromegrass Dominated), 3) co-dominated by Kentucky bluegrass and smooth bromegrass (Co-Dominated), 4) warmseason native grass primarily big bluestem (Andropogon geradii Vitman; Native Dominated), and 5) a mix of exotic species including Kentucky bluegrass, smooth bromegrass, crested wheatgrass (Agropyron cristatum [L.] Gaertn.), and leafy spurge (Euphorbia esula L.; Exotic Mix Dominated). As is common on northern Great Plains rangelands, some community categories were within close proximity to each other. However, most community categories were separated by 50 $100 \mathrm{~m}$ because of plot size requirements for the restoration treatments.

The experimental design was a nested design with site nested within community category and each of the restoration treatments occurring within each community category. Within each plant community category, six $10 \times 30 \mathrm{~m}$ plots were established. Each plot was randomly assigned to one of six treatments. Treatments were 1) control, 2) burned only (Burn), 3) burned and then sprayed with imazapic (Burn/Herbicide), 4) treated with imazapic only (Herbicide Only), 5) mowed but not raked (Mowed), and 6) mowed and then raked (Mowed/ Raked). In 2003 burning was done in the last week of April, and all other treatments were applied when smooth bromegrass was $10-15 \mathrm{~cm}$ tall. In the plots that were mowed, the vegetation was reduced to a maximum estimated height of $15 \mathrm{~cm}$. In the Mowed/Raked treatment, litter was removed by power raking down to the soil surface following mowing. Imazapic was sprayed over the entire plot on the Herbicide 
Only and the Burn/Herbicide treatments at a rate of 511.62 $\mathrm{mL}$ ai $\cdot \mathrm{ha}^{-1}$. In 2004, treatments were repeated on all the communities except for the Burn/Herbicide treatment. Only the Native Dominated community category had sufficient litter to reburn the Burn/Herbicide treatments in 2004. Therefore, only the Native Dominated community categories were reburned in this treatment. However, imazapic was resprayed on all of the Burn/Herbicide plots in 2004 at the same rate as 2003.

Within each plot, three permanent quadrats $\left(0.05 \mathrm{~m}^{2}\right)$ were established in the fall of 2002. The permanent quadrats were randomly located along a transect in each plot. Relative species composition was determined by counting number of individual live grass tillers and forb stems for each species within the quadrats in the fall of 2002, 2003, 2004, and 2005. Each individual species was tallied separately in the field but then they were divided into the following species groups for evaluation purposes: 1) Kentucky bluegrass, 2) smooth brome, 3 ) other introduced grasses and forbs (Other), 4) native grass, and 5) native forb. The Other category was primarily composed of crested wheatgrass, leafy spurge, and yellow sweetclover (Melilotus officinalis [L.] Lam.).

For each species group, we evaluated whether they increased or decreased in abundance in response to the restoration treatments within each of the five community types. This was done by subtracting the percentage in the relative species composition of each species group in the autumn of 2003, 2004, and 2005 from the baseline of autumn 2002. Results were presented as the relative change in species composition over time. The use of relative change in species composition is limited in that it does not indicate whether Kentucky bluegrass or smooth bromegrass absolute tiller numbers are increasing or decreasing. However, the use of relative species composition does provide advantages that we felt outweighed this disadvantage. Relative species composition is a concept that is familiar with both land managers and researchers and provides a means to place changes in tiller numbers for both introduced and native species in a common context. Therefore, use of relative species composition allows for the evaluation of treatments based on their impact on species composition rather than absolute numbers. We felt that focusing on species composition was appropriate from both an ecological and management perspective.

In October of 2002 and August of the subsequent years, four $0.05-\mathrm{m}^{2}$ quadrats were clipped in each plot at ground level. Biomass was sorted into live and dead grass and forb components.

Precipitation data for November through April of each year and for the long-term average (1913-2006) was collected from a National Weather Service station located $6 \mathrm{~km}$ north of the study site. Precipitation data for May through October was collected from an automated weather station located at the study site.

Data were analyzed using PROC MIXED in SAS (Littell et al. 1996) with year, community category, and treatment being fixed effects and sites (community category), treatment $\times$ sites (community category), and replicate being the random effects. Year was considered the repeated effect and compound symmetry was the co-variance structure. Some of the data were transformed to ensure a normal residual distribution.

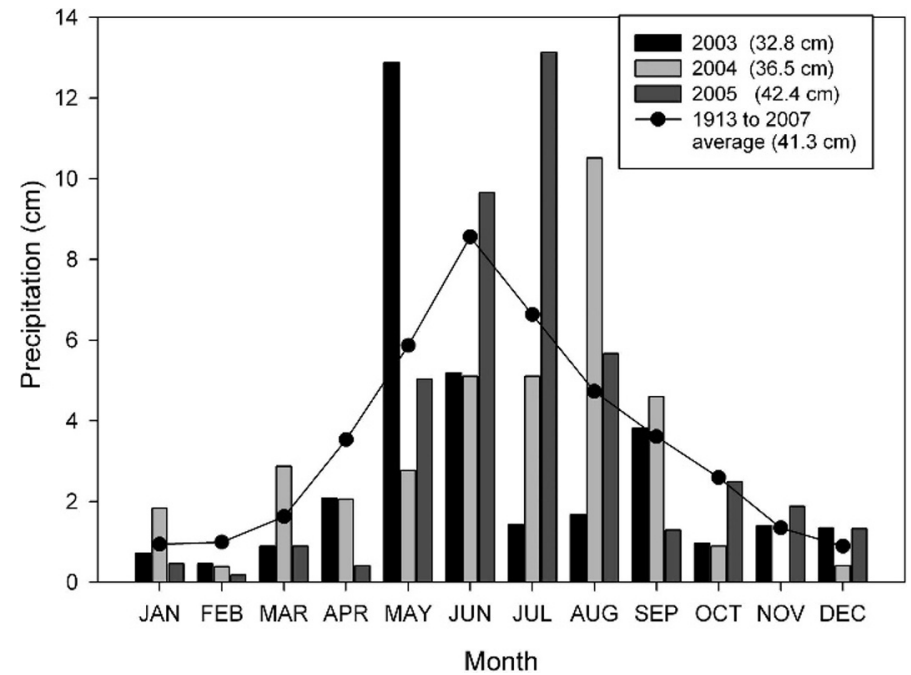

Figure 1. Monthly precipitation (cm) for 2003, 2004, and 2005 (vertical bars) and the long-term average monthly precipitation (line plot) are shown for the Northern Great Plains Research Laboratory in Mandan, North Dakota. Numbers in parentheses in the legend indicate the yearly average precipitation for each year and the long-term average.

Where needed, data were transformed to ensure normal residual distribution. The transformations used are indicated in the respective tables and figures. If needed, outliers were removed by using the UNIVARIATE procedure in SAS (SAS Institute Inc. 2009) to identify extreme observations. Mean separation was done using Tukey mean separation procedure. All means were considered significantly different at a $P$ value $\leq 0.10$ unless otherwise indicated.

\section{RESULTS}

In 2003 and 2004, annual precipitation was less than average long-term annual precipitation, while in 2005 precipitation was slightly greater than average (Fig. 1). The long-term precipitation data show over $70 \%$ of total annual precipitation falls during the 5-mo growing season from May through September. Precipitation during this period was $85 \%, 95 \%$, and $118 \%$ of the long-term average for 2003, 2004, and 2005, respectively (Fig. 1). Although monthly precipitation for May 2003 and August 2004 was over twice the long-term average, the increase in precipitation did not outweigh the lower precipitation during the remaining months (Fig. 1).

\section{Changes in Relative Species Composition}

Year interacted with either community or treatment for each of the major species groups (smooth bromegrass, Kentucky bluegrass, Other, and native grass) except native forbs (Table 1). Because of these interactions, each of the species groups was evaluated by year.

Kentucky Bluegrass. In 2003 and 2004, the response of Kentucky bluegrass to different treatments did not interact with community category, but there was a treatment by community category interaction in $2005\left(\mathrm{~F}_{20,25}=1.94 ; P=0.0592 ; \mathrm{Ta}-\right.$ ble 2). In 2003 and 2004, the Burn/Herbicide treatment 
Table 1. F values for changes in the relative species composition for Kentucky bluegrass, smooth bromegrass, other introduced species (Other), native grasses, native forbs, and live grass biomass using PROC MIXED in SAS.

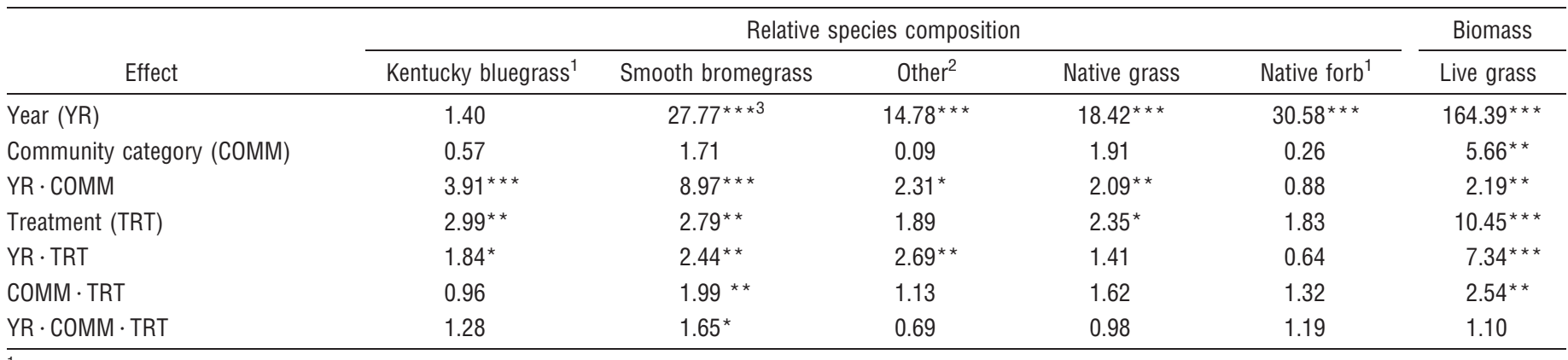

${ }^{1}$ Outliers removed.

${ }^{2}$ Log transformed.

${ }^{3 *}$ indicates significant at $P \leq 0.10 ;{ }^{* *}, P \leq 0.05 ;{ }^{* * *}, P \leq 0.01$.

reduced Kentucky bluegrass more than the untreated controls (Table 3). In 2004 the Burn/Herbicide treatment also reduced Kentucky bluegrass more than the Mowed or Mowed/Raked treatments. In 2005 Kentucky bluegrass, in the Smooth Bromegrass Dominated and Kentucky Bluegrass Dominated community categories, responded differently to treatments when compared to other community categories and the responses of these communities in 2003 and 2004 (Fig. 2A) although none of the treatments were different from the controls.

Native Grasses and Forbs. In 2004 native grass increased in the relative species composition in the Native Dominated community category compared to small increases or decreases in the other community categories $(10.68 \pm 4.4 \%$ vs. $-3.68 \pm$ $4.4 \%, 0.21 \pm 4.4 \%, 0.73 \pm 4.4 \%$, and $1.68 \pm 4.4 \%$; mean \pm $\mathrm{SE}$ for Smooth Bromegrass Dominated, Exotic Mix Dominat-

Table 2. $F$ values for change in relative species composition for community category (COMM) and treatment (TRT) and their interaction for Kentucky bluegrass, smooth bromegrass, native grasses, and other introduced species (Other) by year for 2003, 2004, and 2005.

\begin{tabular}{|c|c|c|c|}
\hline & & Year & \\
\hline & 2003 & 2004 & 2005 \\
\hline Kentucky bluegra & & & \\
\hline СOMM & 1.10 & 1.21 & 0.05 \\
\hline TRT & $2.29 * 1$ & $3.54^{\star \star}$ & $4.21^{\star \star *}$ \\
\hline COMM · TRT & 1.20 & 0.84 & $1.94^{*}$ \\
\hline Smooth bromeg & & & \\
\hline сOMM & $3.57^{* *}$ & $2.41^{*}$ & 1.41 \\
\hline TRT & $2.56^{\star}$ & $3.08^{\star \star}$ & $3.00^{* *}$ \\
\hline COMM · TRT & $3.08^{\star * \star}$ & $2.09^{\star \star}$ & 1.12 \\
\hline Native grasses & & & \\
\hline СOMM & 1.67 & $3.26^{\star \star}$ & 0.21 \\
\hline TRT & 1.78 & 1.72 & $2.79^{\star \star}$ \\
\hline COMM · TRT & 1.04 & 0.99 & $2.31^{\star *}$ \\
\hline Other & & & \\
\hline COMM & 0.29 & 0.19 & 1.11 \\
\hline TRT & 1.73 & $3.28^{* *}$ & 1.50 \\
\hline COMM · TRT & 0.61 & 1.05 & $2.15^{\star \star}$ \\
\hline
\end{tabular}

1*indicates significant at $P \leq 0.10 ;{ }^{* *}, P \leq 0.05 ;{ }^{* *}, P \leq 0.01$.

${ }^{2}$ BRIN was log-transformed for years 2003 and 2004. ed, Kentucky Bluegrass Dominated, and Co-Dominated community categories, respectively). In 2005 there were differences between treatments in the Native Dominated and Kentucky Bluegrass Dominated community categories (Fig. 2B). Native grasses in the Native Dominated community category significantly increased under the Burn/Herbicide treatment but decreased in the Mowed, Mowed/Raked treatments or the untreated control plots. However, in the Kentucky Bluegrass Dominated community category, the Burn/Herbicide treatment decreased native grasses compared to the Burn treatment (Fig. 2B) but neither differed from the control.

Native forbs were only affected by year $\left(\mathrm{F}_{2,60}=30.58\right.$; $P<0.0001$; Table 2). The change in the percent native forbs in the relative species composition compared to 2002 was greater for 2004 and 2005 than for 2003 (1\% and $0.9 \%$ increase in 2004 and 2005 , respectively, compared to a $0.1 \%$ increase in 2003).

Smooth Brome. In 2003 and 2004, the response of smooth brome to different treatments was limited to the Smooth Bromegrass Dominated community category. In 2003 smooth brome increased more in the Herbicide Only treatments than the untreated control or the Mowed treatments (Fig. 3A), but in 2004 treatment responses of smooth brome did not differ from the untreated controls (Fig. 3B). By 2005 the community category by treatment interaction had disappeared $\left(\mathrm{F}_{20,25}=\right.$ 1.12; Table 2), but smooth brome was reduced more by Mowed/Raked treatment $(-5.94 \pm 2.8 \%)$ than by the Herbicide Only treatment $(2.13 \pm 2.8 \%)$ or the untreated control $(3.08 \pm 2.8 \%)$.

Table 3. Absolute change in relative species composition (SE) for fall 2003 and 2004 compared to the baseline of fall 2002 for Kentucky bluegrass. Different lowercase letters within each column indicate significant differences at $P<0.10$.

\begin{tabular}{lcc}
\hline \multirow{2}{*}{ Treatment } & \multicolumn{2}{c}{ Year } \\
\cline { 2 - 3 } Control & $-0.6(3.3) \mathrm{b}$ & $-2.1(5.5) \mathrm{bc}$ \\
Burn & $-5.6(3.3) \mathrm{ab}$ & $-13.9(5.5) \mathrm{ab}$ \\
Burn/Herbicide & $-10.4(3.3) \mathrm{a}$ & $-16.8(5.5) \mathrm{a}$ \\
Herbicide only & $-1.5(3.4) \mathrm{ab}$ & $-3.8(5.5) \mathrm{abc}$ \\
Mowed & $-2.6(3.3) \mathrm{ab}$ & $-1.3(5.5) \mathrm{bc}$ \\
Mowed/Raked & $-3.7(3.3) \mathrm{ab}$ & $0.8(5.5) \mathrm{c}$ \\
\hline
\end{tabular}




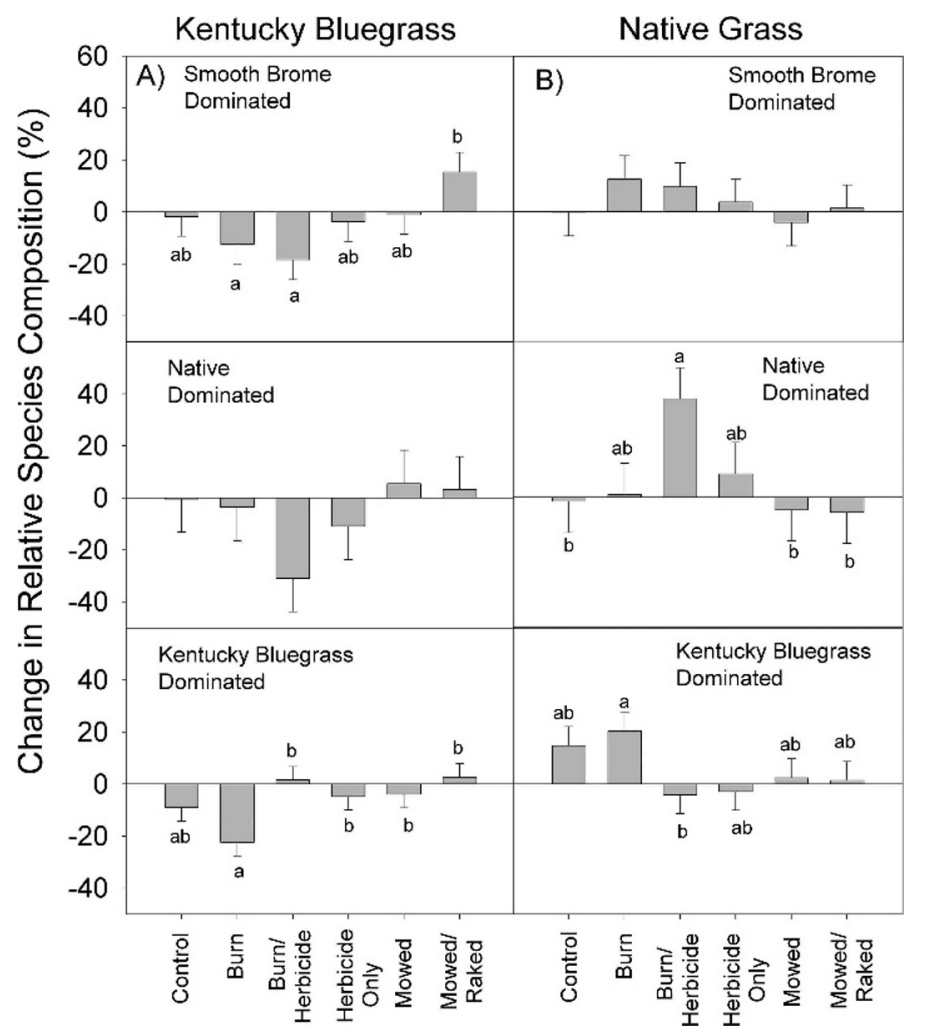

Figure 2. Percent change in relative species composition between an autumn 2002 baseline and autumn 2005 for Kentucky bluegrass (A) and native grass (B) in response to different treatments for Smooth Brome Dominated, Native Dominated, and Kentucky Bluegrass Dominated community categories. The Exotic Mix Dominated and Co-Dominated community categories did not have significant treatment differences and are not shown in the graph.

Other Invasive Species (Other). The Other category was composed of a mix of other introduced grasses and forbs. This category had treatment differences in $2004\left(\mathrm{~F}_{5,25}=3.28\right.$; $P=0.0206$; Table 2) and a treatment by community interaction in $2005\left(\mathrm{~F}_{20,25}=2.15 ; P=0.0358\right.$; Table 2$)$. Between 2002 and 2004 the Other category was increased more by the Burn Only treatment $(12.39 \pm 2.9 \%)$ than by the Mowed/ Raked treatment $(1.48 \pm 2.9 \%)$ or the untreated controls $(4.04 \pm 2.9 \%)$. In 2005 Other invasive species increased more in the Burn/Herbicide treatments $(14.88 \pm 3.0 \%)$ than in the Burn Only $(1.63 \pm 3.0 \%)$, Herbicide Only $(1.78 \pm 3.0 \%)$, or Mowed/Raked $(2.06 \pm 3.0 \%)$ treatments in the Exotic Mix Dominated community category. In the Kentucky Bluegrass Dominated community, Other invasive species increased more in the Herbicide Only treatment $(7.04 \pm 2.3 \%)$ than they were reduced in the Mowed/Raked treatment $(5.20 \pm 2.3 \%)$. In both the Co-Dominated and Kentucky Bluegrass Dominated community categories, treatments did not differ from the controls and there were no differences between treatments in the other community categories in 2005 .

\section{Live Biomass}

Live grass biomass had interactions between year and treatment $\left(\mathrm{F}_{10,60}=7.34 ; P<0.0001\right)$ and year and community category $\left(\mathrm{F}_{8,60}=2.19 ; P=0.0412\right.$; Table 1$)$. Therefore, live grass biomass was analyzed by year. In 2003 there was a

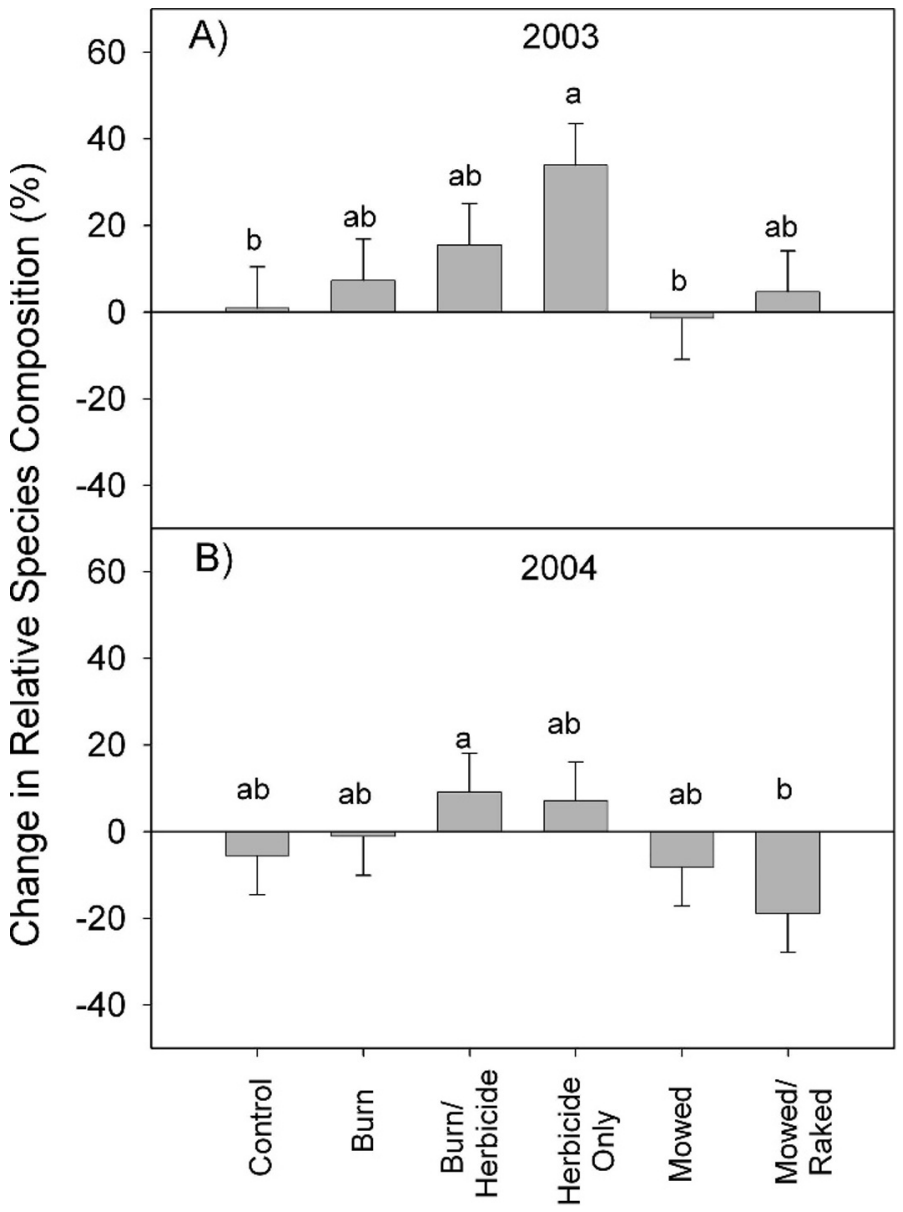

Figure 3. Percent change in relative species composition for smooth brome among autumn 2002, (A) 2003, and (B) 2004 in response to different treatments in the Smooth Brome Dominated community category only. There were no significant treatment differences in the other community categories.

treatment by community category interaction for live grass biomass $\left(F_{20,25}=2.45 ; P=0.0178\right)$. In 2004 there were differences between treatments $\left(\mathrm{F}_{5,25}=8.52 ; P<0.0001\right)$ and community categories $\left(\mathrm{F}_{4,5}=10.62 ; P=0.0116\right)$ for live grass biomass. In 2005 live grass biomass had no differences for either treatment or community category.

2003 Live Grass Biomass. The Burn/Herbicide treatment produced significantly less live grass biomass than any of the other treatments in the Co-Dominated community category and produced less live grass biomass than the Burn Only, Herbicide Only, and control treatments in the Smooth Bromegrass Dominated community category (Fig. 4). The Burn/Herbicide treatment also reduced biomass production compared to Burn Only treatment in the Kentucky Bluegrass Dominated community, but was not different from the control (Fig. 4).

2004 Live Grass Biomass. In 2004 the Burn/Herbicide $\left(1470.1 \pm 212.9 \mathrm{~kg} \cdot \mathrm{ha}^{-1}\right)$ and Herbicide Only treatments $\left(1385.2 \pm 212.9 \mathrm{~kg} \cdot \mathrm{ha}^{-1}\right)$ produced less live grass biomass than Burn Only $\left(1734.4 \pm 212.9 \mathrm{~kg} \cdot \mathrm{ha}^{-1}\right)$, Mowed (1827.1 \pm $\left.212.9 \mathrm{~kg} \cdot \mathrm{ha}^{-1}\right)$, or Mowed/Raked $\left(1829.6 \pm 212.9 \mathrm{~kg} \cdot \mathrm{ha}^{-1}\right)$ treatments or the untreated control $\left(2207.8 \pm 212.9 \mathrm{~kg} \cdot \mathrm{ha}^{-1}\right)$. 
The Native Dominated community category produced more live grass biomass $\left(3241.1 \pm 493.9 \mathrm{~kg} \cdot \mathrm{ha}^{-1}\right)$ than did any other community $(1431.4 \pm 493.9,1339.6 \pm 493.9,1176.4 \pm 493.9$, and $1523.3 \pm 493.9 \mathrm{~kg} \cdot \mathrm{ha}^{-1}$ for Smooth Bromegrass Dominated, Exotic Mix Dominate, Kentucky Bluegrass Dominated, and Co-Dominated community categories, respectively).

Live Forb Biomass. There were differences between years in live forb biomass $\left(\mathrm{F}_{2,60}=9.03 ; P=0.0004\right)$. There was less live forb biomass in 2004 than in 2003 or $2005\left(136.5 \pm 62.2 \mathrm{~kg} \cdot \mathrm{ha}^{-1}\right.$ vs. $266.5 \pm 62.2$ and $365.8 \pm 62.2 \mathrm{~kg} \cdot \mathrm{ha}^{-1}$ for 2003 and 2005 , respectively).

\section{DISCUSSION}

Rangeland managers have a variety of management tools for restoring rangelands. However, often the effectiveness of a technique is evaluated by considering the impact on the population of a target species without considering the effects at the community level (DiTomaso et al. 2006). By evaluating the effectiveness of different restoration treatments and treatment combinations on two different invasive perennial grass species, we have shown that the most effective treatment for an invasive grass species will vary depending on the community it is found in and other factors such as yearly rainfall. Treatments responses changed over time, which suggests that incorporating active adaptive management strategies (Shea et al. 2002; McCarthy and Possingham 2007) may be an appropriate basis for developing strategies for management of invasive species.

Kentucky bluegrass and smooth bromegrass are often found on the same rangelands (Murphy and Grant 2005), and both grasses may visibly dominate a community as demonstrated by our Co-Dominated community category. Although both species are perennial $\mathrm{C}_{3}$ grasses (Waller and Lewis 1979), they had different responses to treatments. Kentucky bluegrass became less dominant within the relative species composition with the Burn Only or the Burn/Herbicide treatments across all communities in the first $2 \mathrm{yr}$ following treatment initiation. However, reducing the dominance of smooth brome occurred on plots that were mowed, and plant material was removed by raking (Mowed/Raked treatment). Over time, Kentucky bluegrass responses to treatment tended to differ between community categories while the impact of community categories on smooth brome responses to treatment was reduced over time, and by 2005 the response of smooth brome to treatments was similar for all five communities.

Differences in the responses of the two species may have occurred for several reasons. First, smooth brome may have been burned too early for maximum impact. Fire has the biggest impact on smooth brome tiller density when burning is conducted at tiller elongation or later (Mitchell et al. 1996; Willson and Stubbendieck 1997). Information on the relationship between morphological development and growing degree day (Frank 1996; Frank et al. 1997) indicates that smooth brome would have still been in the vegetative stage when burning occurred. However, Kentucky bluegrass may have also benefited from a later burn date. In the northern Great Plains, there is some evidence that burning later such as mid-May can

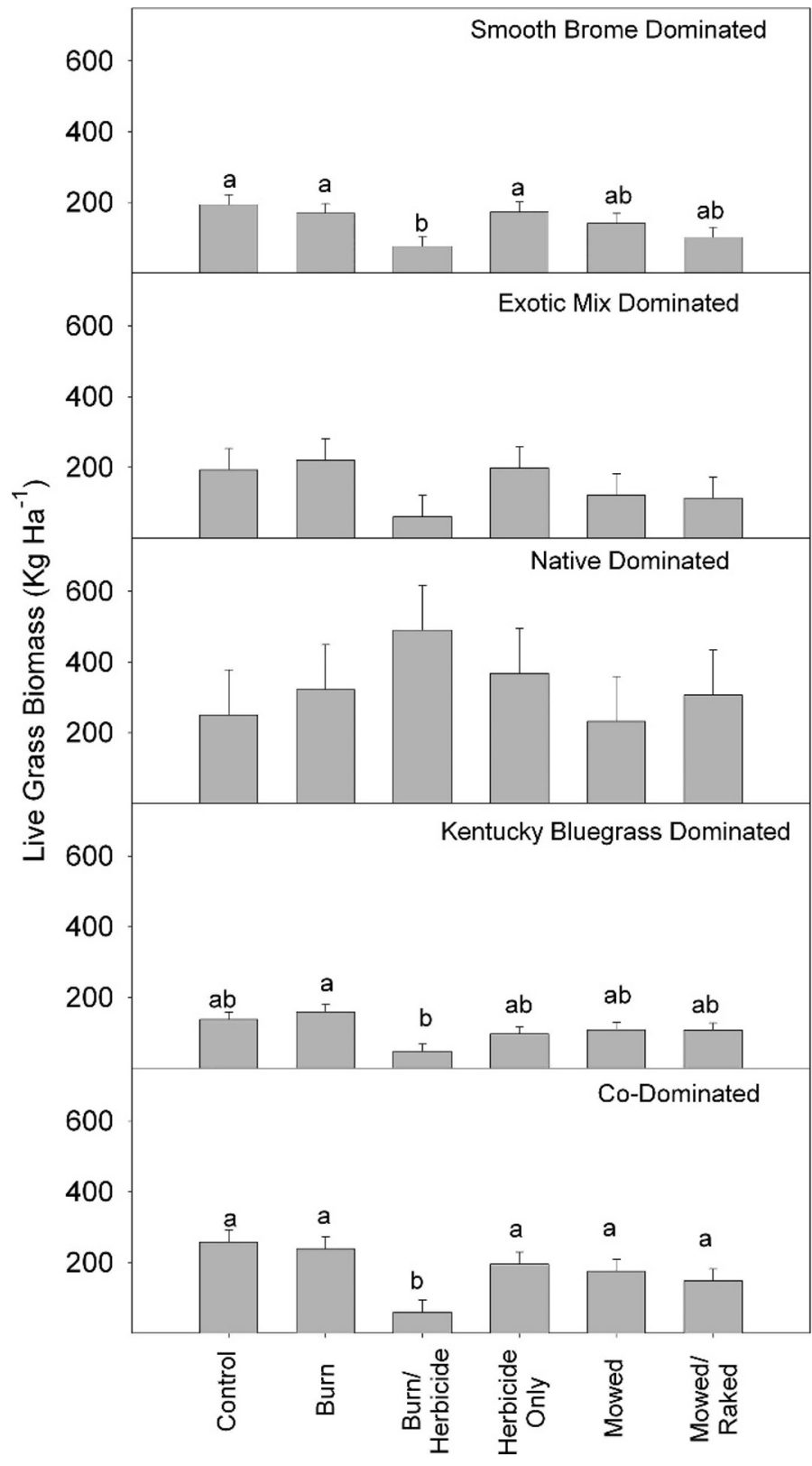

Figure 4. Responses of live grass biomass to different restoration treatments in Smooth Brome Dominated, Exotic Mix Dominated, Native Dominated, Kentucky Bluegrass Dominated, and Co-Dominated community categories for 2003.

also reduce Kentucky bluegrass at least during dry years (Engle and Bultsma 1984). Fire was applied to the Burn Only plots for two consecutive years, and repeated burns have been shown to reduce both Kentucky bluegrass (Knops 2006) and smooth brome (Stacy et al. 2005).

Second, the two invasive species responded differently to burning followed by herbicide application. For example, the Burn/Herbicide treatment generally decreased Kentucky bluegrass especially in 2003 and 2004 but had no significant impact on the abundance of smooth brome. Kentucky bluegrass has been shown to be more susceptible to other types of herbicides, such as atrazine, than smooth brome (Masters et al. 1992). Also, burning removed the heavy thatch layer characteristic of a Kentucky bluegrass dominated site, which may have 
improved herbicide effectiveness (DiTomaso et al. 2006). Burning followed by imazapic (Burn/Herbicide) restricted live grass biomass in most community categories in 2003, reducing thatch for the second application of imazapic in 2004. Imazapic has been successfully used to enhance the seedling establishment of warm-season grasses (Masters et al. 1996), so the success of a burning and herbicide application in enhancing the native grass abundance on the primarily big bluestemdominated native communities was not surprising. However, in the cool-season-dominated communities, burning followed by imazapic (Burn/Herbicide) often decreased live grass biomass although the negative impact on live grass had disappeared by the end of the study.

The third potential reason for the different species responses to treatment is differences in responses to defoliation. The Mowed/Raked treatment, which was mowing followed by raking, resulted in the greatest reduction in smooth brome abundance but either increased or had limited impact on Kentucky bluegrass responses. The different responses may be linked to differences in plant morphology. The short stature of Kentucky bluegrass limits tissue accessibility and keeps apical meristems near the soil surface, limiting exposure to defoliation (Briske 1991). Smooth brome, which has more exposed meristems, tends to decrease under grazing (Murphy and Grant 2005; Stacy et al. 2005).

Although we only had two sites per community category, our data suggest that treatment responses can be impacted by community type. This was especially evident in 2005 when Kentucky bluegrass, native grasses, and Other species responded differently to restoration treatments in different community categories. Some restoration treatments by community category interactions were easy to interpret. Imazapic targets coolseason $\left(\mathrm{C}_{3}\right)$ grasses, such as those that dominated the Kentucky Bluegrass Dominated and Co-Dominated community categories, but does not negatively impact big bluestem, a $\mathrm{C}_{4}$ species, which dominated the Native Dominated community (Masters et al. 1996). Therefore, the native grass component would be expected to increase in the Native Dominated community category. June, July, and August had greater precipitation than normal in 2005, which would also benefit the warm-season native species in the native community.

Other interactions are more difficult to explain. In 2005 the Burn/Herbicide treatment reduced Kentucky bluegrass by nearly $20 \%$ in the relative species composition in the Smooth Bromegrass Dominated community categories but had limited impact in the Kentucky Bluegrass Dominated community category. Among the possible explanations are treatmentinduced changes in interspecies composition and below-ground processes. Competition has major impacts on plant responses (Mueggler 1972) and both smooth brome (Nernberg and Dale 1997) and Kentucky bluegrass (Tilman and Wedin 1991) are highly competitive, especially in fertile environments. In general, the Burn/Herbicide treatment increased the amount of smooth brome in the species composition while decreasing Kentucky bluegrass. Disturbances have been reported to favor one species over another (Buckley et al. 2007; Firn et al. 2008) as well as the subsequent colonization. This may have shifted the competitive interactions to favor smooth brome in the Smooth Brome Dominated community. Alternatively, restoration treatments may have impacted below-ground processes.
Smooth brome has been reported to exhibit self-facilitation through soil modification (Jordan et al. 2007), and soil microorganisms can impact community structure and diversity (Hartnett and Wilson 1999). The direct mechanism is unknown because neither direct competition nor below-ground processes were directly measured in our study. The different responses between community categories emphasize the need to plan for responses at the community as well as the population level (DiTomaso et al. 2006).

Treatment responses were also affected by year. The year effect is illustrated by smooth brome treatment responses becoming more similar between communities, but Kentucky bluegrass and the Other species treatment responses became less similar between communities. The year effect was also evidenced with the native forb and live grass biomass responses. The impact of year may have been driven by differences in precipitation, such as the effect of increased precipitation on native forbs in 2004 and 2005. Increased precipitation during June, July, and August may have also increased responses of the primarily $\mathrm{C}_{4}$ grasses in the Native Dominated community category. Other factors driving the year effect may have been the cumulative impact of treatments when applied more than once. Most treatments were applied for two consecutive years when possible, and this frequency may have impacted outcomes. Fire frequency can impact Kentucky bluegrass (Knops 2006), and repeated fire or grazing reduces smooth brome (Stacy et al. 2005). Time can also affect the response of invasive species to herbicides. For example, herbicide control of Canada thistle (Cirsium arvense [L.] Scop.) has been shown to change over time (Travnicek et al. 2005). The changes in treatment responses over time highlight the importance of long-term planning and monitoring in an invasive plant control strategy.

\section{MANAGEMENT IMPLICATIONS}

Control of invasive perennial grasses is a difficult and complex task. Our study pointed out the importance of considering which invasive species is targeted, the community the invasive species is in, and the importance of monitoring invasive species responses to treatment. The different responses of these two perennial invasive grasses indicated that the same treatment would produce different responses. Kentucky bluegrass was reduced most consistently by Burn/Herbicide treatment, but this same treatment increased smooth bromegrass. Similar effects could be seen with the Mowed/Raked treatment. This treatment, which mimicked a grazing situation most closely, reduced the abundance of smooth bromegrass but increased Kentucky bluegrass.

Our data also showed the influence of community category on treatment responses. Treatments to control the same invasive species had different effectiveness depending on the dominant species in the community category. Also, the use of the Burn/Herbicide treatment in all of the community categories, except the warm-season native, severely limited live grass productivity, which would be a concern for land managers. The land manager would need to determine if potential enhancements in species composition are worth the initial decline in productivity. Finally, the changes in treatment 
responses over time showed the importance of incorporating active adaptive management (Shea et al. 2002; McCarthy and Possingham 2007) techniques into invasive species control strategies. As an example, if this study was concluded after year 2 , our results would have been limited, and our management recommendations would have been different. Effective management strategies for controlling Kentucky bluegrass and smooth brome need to consider species, community composition, and length of time since the treatments were applied.

\section{ACKNOWLEDGMENTS}

The authors would like to acknowledge M. K. Tokach, S. Piper, C. Hager, J. Kramlich, and A. Fischer for data collection and entry, and L. Vermeire, R. Mitchell, and S. Kronberg for helpful comments on earlier versions of the manuscript.

\section{LITERATURE CITED}

BRISKE, D. D. 1991. Developmental morphology and physiology of grasses. In: R. K. Heitschmidt and J. W. Stuth [EDS.]. Grazing management: an ecological perspective. Portland, OR, USA: Timber Press. p. 85-108.

BuCKLEY, Y. M., B. M. Bolker, AND M. ReEs. 2007. Disturbance, invasion and reinvasion: managing the weed-shaped hole in disturbed ecosystems. Ecology Letters 10:809-817.

Ditomaso, J. M., M. L. Brooks, E. B. Allen, R. Minnich, P. M. Rice, and G. B. Kyser. 2006. Control of invasive weeds with prescribed burning. Weed Technology 20:535-548.

Engle, D. M., and P. M. Bultsma. 1984. Burning of Northern mixed prairie during drought. Journal of Range Management 37:398-401.

Facelli, J. M., and S. T. A. Pickett. 1991. Plant litter: its dynamics and effects on plant community structure. Botanical Review 57:1-32.

Firn, J., T. Rout, H. Possingham, and Y. M. Buckley. 2008. Managing beyond the invader: manipulating disturbance of natives simplifies control efforts. Journal of Applied Ecology 45:1143-1151.

Frank, A. B. 1996. Evaluating grass development for grazing management. Rangelands 18:106-109.

Frank, A. B., J. D. Berdahl, and J. F. Karn. 1997. Phyllochron development in coolseason forage grasses. In: Proceedings of the XVIII International Grassland Congress; 8-19 June 1997; Winnipeg, Manitoba, Canada. p. 7-17-7-18.

Grant, T. A., B. Flanders-Wanner, T. L. Shaffer, R. K. Murphy, and G. A. Knutsen. 2009. An emerging crisis across northern prairie refuges: prevalence of invasive plants and a plan for adaptive management. Ecological Restorations 27:58-65.

Hartnett, D. C., and G. W. T. Wilson. 1999. Mycorrhizae influences plant community structure and diversity in tallgrass prairie. Ecology 80:1187-1195.

Hendrickson, J. R., B. J. Wienhold, and J. D. Berdahl. 2001. Comparison of decomposition rates between native and improved grasses in the Northern Great Plains. Arid Land Research and Management 15:247-257.

Jordan, N. R., D. L. Larson, and S. C. Huerd. 2007. Soil modification by invasive plants: effects on the native and invasive species of mixed-grass prairies. Biological Invasions 10:177-190.

Knapp, A. K., And T. R. Seastedt. 1986. Detritus accumulation limits productivity of tallgrass prairie. Bioscience 36:662-668.

Knops, M. H. 2006. Fire does not alter vegetation in infertile prairie. Oecologia 150:477-483.

Littell, R. C., G. A. Milliken, W. W. Stroup, and R. D. Wolfinger. 1996. SAS system for mixed models. Cary, NC, USA: SAS Institute Inc. 633 p.
Masters, R. A., S. J. Nissen, R. E. Gaussoin, D. D. Beran, and R. N. Stougafrd. 1996. Imidazolinone herbicides improve restoration of Great Plain grasslands. Weed Technology 10:392-403.

Masters, R. A., K. P. Vogel, and R. B. Mitchell. 1992. Response of Central Plains grasslands to fire, fertilizer, and atrazine. Journal of Range Management 45:291-295.

McCarthy, M. A., and H. P. Possingham. 2007. Active adaptive management for conservation. Conservation Biology 21:956-963.

Mitchell, R. B., R. A. Masters, S. S. Waller, K. J. Moore, and L. J. Young. 1996. Tallgrass prairie vegetation response to spring burning dates, fertilizer, and atrazine. Journal of Range Management 49:131-136.

MueggleR, W. F. 1972. Influence of competition on the response of bluebunch wheatgrass to clipping. Journal of Range Management 25:88-92.

Murphy, R. K., And T. A. Grant. 2005. Land management history and floristics in mixed-grass prairie, North Dakota, USA. Natural Areas Journal 25:351-358.

Nermberg, D., and M. R. T. Dale. 1997. Competition of five native prairie grasses with Bromus inermus under three different moisture regimes. Canada Journal of Botany 75:2140-2145.

Pritekel, C., A. Wittemore-Olson, N. Snow, and J. C. Moore. 2006. Impacts from invasive plant species and their control on the plant community and belowground ecosystem at Rocky Mountain National Park, USA. Applied Soil Ecology 32:132-141.

Reed, H. E., T. R. Seastedt, and J. M. Blair. 2005. Ecological consequences of $\mathrm{C}_{4}$ grass invasion of a $\mathrm{C}_{4}$ grassland: a dilemma for management. Ecological Applications 14:1560-1569.

SAS Institute Inc. 2009. Base SAS ${ }^{\circledR} 9.2$ procedure guide. Cary, NC, USA: SAS Institute Inc. $1680 \mathrm{p}$.

Schacht, W., and J. Stubbendieck. 1985. Prescribed burning in the loess hills mixed prairie of southern Nebraska. Journal of Range Management 38:47-51.

Schacht, W., And J. Stubbendeck. 1985. Prescribed burning in the loess hills mixed prairie of southern Nebraska. Journal of Range Management 38:47-51.

Shea, K., H. P. Possingham, W. W. Murdock, and R. Roush. 2002. Active adaptive management in insect pest and weed control: intervention with a plan for learning. Ecological Applications 12:927-936.

Stacy, M. D., B. L. Perryman, P. D. Stahl, and M. A. Smith. 2005. Brome control and microbial inoculation effects in reclaimed cool-season grasslands. Rangeland Ecology and Management 58:161-166.

Suding, K. N., And D. E. Goldberg. 1999. Variation in the effects of vegetation and litter on recruitment across productivity gradients. Journal of Ecology $87: 436-449$

Tilman, D., And D. A. Wedin. 1991. Plant traits and resource reduction for five grasses growing on a nitrogen gradient. Ecology 72:685-700.

Travnicek, A. J., R. G. Lym, and C. Prosser. 2005. Fall-prescribed burn and springapplied herbicide effects on Canada thistle control and soil seedbank in a northern mixed-grass prairie. Rangeland Ecology and Management 58: 413-422.

Vaness, B. M., AND S. D. WiLson. 2007. Impact and management of crested wheatgrass (Agropyron cristatum) in the northern Great Plains. Canada Journal of Plant Science 87:1023-1028.

Waller, S. S., AND J. K. Lewis. 1979. Occurrence of $C_{3}$ and $C_{4}$ photosynthetic pathways in North American grasses. Journal of Range Management 32:12-28.

Wedin, D. A., and D. TILman. 1996. Influence of nitrogen loading and species composition on the carbon balance of grasslands. Science 274:1720-1723.

WiLLson, G. D. 1990. Morphological characteristics of smooth brome used to determine a prescribed burn date. In: D. D. Smith and C. A. Jacobs [EDs.]. Proceedings of the 12th North American Prairie Conference: Recapturing a Vanishing Heritage; 5-9 August 1990. Cedar Falls, IA, USA: University of Northern lowa. p. 113-116.

Willson, G. D., and J. Stubbendieck. 1997. Fire effects on four growth stages of smooth brome (Bromus inermis, Leyess.). Natural Areas Journal 17:306-312.

XIONG, S., And C. NiLsson. 1999. The effects of plant litter on vegetation: a metaanalysis. Journal of Ecology 87:984-994. 